\title{
Jojoba Leaf Extract Induced Nematocide Effect Upon Meloidogyne incognita
}

\author{
Amira. M. Khatab ${ }^{1}$ and M. A. Seehy ${ }^{2}$
}

\begin{abstract}
This work aims at disclosing the capability of Jojoba leaf extract to induce nematocide effect upon Meloidogyne incognita. To achieve such a purpose adventitious roots of Allium cepa were employed. Furadan as a well known nematocide was chosen and used for the comparison. Tomatto seedlings were treated with $M$. incognita and soil was treated either with Furadan or Jojoba leaf extract. Mitotic index and chromosomal abnormalities were estimated. The obtained results revealed that the Jojoba leaf extract was proven to be active as nematocide agent .
\end{abstract}

\section{INTRODUCTION}

$\mathrm{n}$ Egypt, jojoba is considered as one of the most practical solutions for desert plantation because its ability for tolerance to heat, drought and salt, lesser possibilities for infection, lesser need for fertilizers, and generous financial income, are certainly the most encouraging goals to plant jojoba in Egypt for revegetation of arid areas as it can survive in harsh desert environments; this is so in Mexico, Israel and in Rajasthan India, so that El Moguy (2002) was the first who mentioned the first practical steps to introduce jojoba to Egypt by planting the first jojoba field surrounded by date palms with the technical help of an agricultural expert, and the help of the FAO coordinator. The plant is important to commerce as its seeds oil store (40-60 \% by dry weight). Its seed oil is a unique liquid wax ester mixture highly marketable for cosmetics and lubricants. It has promising physical properties, such as high viscosity index, high stability and freezing point, and can be used in various industries. It dose not get damaged or rancid by repeated heating to temperatures above $300^{\circ} \mathrm{C}$.

The viscosity index of jojoba oil is much higher than that of petroleum oil, and it is therefore being used as a high temperature and high pressure lubricant in heavy machinery. In addition to this, it is also being used in transformer oil, detergents, the leather and plastic industries, and in pharmaceutical as well as cosmetic industries. Jojoba oil contains straight- chained $\mathrm{C}_{20}$ and $\mathrm{C}_{22}$ fatty acids and alcohols and two unsaturated bonds, which make the oil susceptible to many different types of chemical manipulations. The extracted oil is relatively pure, non-toxic, biodegradable, and resistant to rancidity.
On the other hand, the seed meal remaining after extraction of the oil has some uses it is mostly discarded. The rest of jojoba seed contains 25-30\% crude protein and has potential as an animal feed supplement (Flo et al.,1998; Jones and Lewis, 1999 \& 2001; Brown, 2003 and Motawe, 2006) or partial replacement of fish meal by jojoba meal supplemented with Methionine and Biogen ${ }^{\circledR}$ for fish feeding (khalil et al., 2009).

Jojoba is a promising oil crop and as the bushes are perennials, there will be a continuous supply of seed annually. This, and other advantagees of the jojoba trees, such as soil conservation and as wind breaks add tremendously to the values of jojoba and to ensure further development of jojoba as a commercial crop. It is crucial to identify the factors that contribute to the extreme variability observed in different genotypes. Identification of genotypes capable of ensuring both profitable yield and wide genetic variability will be a challenging task that will require a complete set of information in order to understand how a given phenotype is constituted at the molecular. Biochemical, reproductive and agronomic level, therby facilitating the rapid identification of molecular and metabolic markers that are important to define a required phenotype. A multidisciplinary approach based on molecular genetics, functional genomics, plant reproductive biology, biochemistry and agronomy will provide accurate information with which to identify genotypes with stabilized yield in various production systems. In vitro clonal propagation has a major advantage over seed propagation in that it allows propagation of unique genotypes which have been identified as being desirable. It allows as propagating plants of known sex, or of known high-yield potential, or of other desirable characteristics.

This study was planned to investigate the effect of nematicide (Furadan 10G) on the nematode development compared with the effect of Jojoba leaves. However to diclose the capability of Furadan in inducing genotoxic effect on higher plant, Onion (Allium сера) was selected, treated and two genotoxic bioassays were employed. They are : 1- investigation of cell proferation, and 2- analysis of mitotic chromosomal behavior

\footnotetext{
${ }^{1}$ Dept. of Biology Fac.Girls Education Univ .of Elmajmmah Kingdom of Saudi Arabia

${ }^{2}$ Dept. Genetics Fac. Agric. Alexandria University.

Received May 9, 2013, Accepted June 26, 2013
} 


\section{MATERIALS AND METHODS}

Furadan :

\section{Structural Formula}

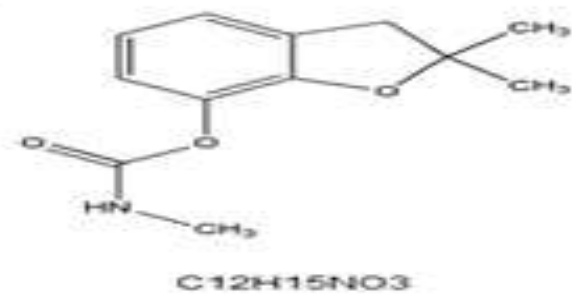

Chemical name: (2,3-dihydro 2,2-dimethyl- 7benzofuranyl methylcarbamate)

Source : (Kafr El-zayat) Company

\section{Root-Knot nematode inoculum preperation:}

Root-Knot nematode,Meloidogyne incognita used in the present study was originally isolated from galled tomato roots. Identefication of the nematode to species was basedon the morphological characteristics of the perineal patterns of adult females according to the key given by Taylor and Sasser (1978).

Effect of Jojoba dry leaves on the development and reproduction of M.incognita:

Effect of jojoba " Simonodsia chinensis" dry leaves on development and reproduction of $\mathrm{M}$. incognita was studied. Twenty pots $(10 \mathrm{~cm}$, diameter) were used in this experiment, each pot contains two tomato (cv. Super Strain B) plants. Pots were divided into five groups each of four replicates. The $1^{\text {St }}$ and $2^{\text {nd }}$ group received milled of jojoba dry leaves at two concentrations 2.5 and $5 \mathrm{~g} /$ pot, respectively. Pots of the $3^{\text {th }}$ and $4^{\text {th }}$ groups received the granular nematicide Furadan ${ }^{\circledR}(10 \mathrm{G})$ z-hich was applied in two concentrations 1.5 and $3 \mathrm{~g} /$ pot. The $5^{\text {th }}$ group was left untreated to serve as a control. Treatments were applied in a hols around the tomato roots, 7 days after tomato transplantation.

After 48 hours from treatments by jojopa or Furadan ${ }^{\circledR}$. Plants were inoculated by 5000 eggs/ pot in a hols around roots of plants.

The fertilizer, (N. P.K) $(20,12,16 \%)$ at the rate of $2 \mathrm{~g} / \mathrm{L}$ was used as foliar application once every 10 days. Sixty days after nematode inoculation, tomato roots were gently removed from the soil and washed with tap water. Number of root galls, egg masses and 2nd stage juveniles/ $250 \mathrm{~g}$ soil were recorded.

\section{Slide preparation and staining:}

The fixed root- tips were thoroughly washed with distilled water then .a single root- tips was placed in a drop of acetocarmine on a dry slide and covered.
Studying the effect of root-knot nematode, M.incoanita on nuclear DNA content of the infected tomato roots:

Tomato seeds were allowed to germinate until an average of seedling height of $10 \mathrm{~cm}$ had reached. Then seedlings were transferred into plastic pots $(10 \mathrm{~cm}$ diameter) each contained two seedlings.

The experiments were divided into three groups. The $1^{\text {St }}$ and $2^{\text {nd }}$ groups were inoculated with $\mathrm{M}$ incognita at the rate of $2000 \mathrm{~J}_{2} /$ pot on the $3^{\text {rd }}$ and $8^{\text {th }}$ day after transplantation; the $3^{\text {rd }}$ group was left noninoculated to serve as a control. Tomato seedlings were inoculated with $\mathrm{M}$ incognita $2000 \mathrm{~J}_{2}$ /pot, Samples of cells were then taken after 15 days from tomato root- tips.

\section{RESULTS AND DISCUSSION}

The present work aims to investigate the capability of Meloidogyne incognita in inducing differential DNA content in higher plant genome. The genotoxic effect of the nematicide Furadan ${ }^{\circledR}$ upon higher plant chromosomes was also investigated. A comparison between the effect of Furadan ${ }^{\circledR}$ and Jojopa leaf extract on the Meloidogyne development was carried out to investigate the nematocide effect of Jojoba leaf extract. In order to achieve such a purpose seedlings of tomato (Lycopersicom esculentum); and onion (Allium cepa) were chosen as higher plant test organism employing the following bioassays:

1- Flow cytometry for differential DNA content;

2- Cell proliferation estimated by measuring mitotic indices;

3- Analysis of mitotic chromosomal behavior; and

4- Investigation of Meloidogyne development.

The present result revealed that nematode populations were reduced with soil treatments of Furadan ${ }^{\circledR}(10 \mathrm{G})$ a Concentration of $1.5 \mathrm{~g}$ and $3 \mathrm{~g}$ (a.i)/ pot, These data show that the nematocide Furadan ${ }^{\circledR}$ was proven to be highly effective on nematode reproduction. This conclusion is in accordance with that reported by Minton (1979), Inserra (1985), Siddqui et al., (1998), Khan et. al (2001) and Amin (2013) .Comparing the effect of Jojoba leaf extract on the nematode development with Furadan $\AA$, The obtained results revealed that the Feuradan was effective significantly in reducing the number of galls, egg masses and $2^{\circ} \mathrm{d}$ stage juveniles of $\mathrm{M}$ incognita at two treatments $2.5 \mathrm{~g}$ and $5 \mathrm{~g}$ drv weight of leaves/ pot compared with the negative control group.

The present work suggests that the tested concentration of $2.5 \mathrm{~g}$ dry weight of Jojoba leaf extract was proven to be effective causing lethality for Meliodogyne incognita more than that of Feuradan. 
Regarding the genotoxic effect of Jojoba leaf extract upon Allium cepa genome, the present study showed that the tested Jojoba leaf extract has chromosomal damaging effect, since different types of aberrations were observed, these aberrations are deletion; gaps; breaks; fragments; stickiness; chromatide bridge; and binucleate. These types of aberrations however gave an evidence that Furadan ${ }^{\circledR}$ has a positive clastogenic activity upon the employed higher plant i.e., Allium cepa genome. Chromatide bridge gave an evidence that Jojoba leaf extract is capable to interfere and/ or alter the net change of the chromosomal proteins (Seehy and Hafez, 1994). This conclusion however is confirmed by the cytological observation of eroded surface obtained from this study. Binucleat cells presented an evidence that the tested nematocide is capable to prevent cell wall formation, and accordingly cytokinesis might be stopped.

This result however presented an evidence that the tested Jojoba leaf extract has molecular activity upon chromosomes and cellular effect as well.

\section{Flow cytometry:}

This step was achieved according to Kevers et al., (1999) as following: suspension of isolated nuclei were kept cold on ice, and stain with an equivalent volume of $1 \mathrm{mg} \mathrm{cm}{ }^{-3}$ propidium iodide (PI) (Sigma, St. Louis, USA). This die was selected because it has an excitation spectrum (peak at $493 \mathrm{~nm}$ ) compatible with the blue argonlaser present on most flow cytometers, and was found to be the best for determining DNA content in plant material (Michaelson et al., 1991). Stained nuclei were analyzed directly in the dye solution. Nuclei were run on a FAC Star+ flow cytometer equipped with the FAC Station Computer Management System (Macintosh Cell Quest Software; Becton Dickinson, Sunyvale, USA) and with an argon- ion laser emitting a 488-nm beam at $200 \mathrm{mw}$ of power (Spinnaker 1161 model; spectra- physics, mountain view, USA).
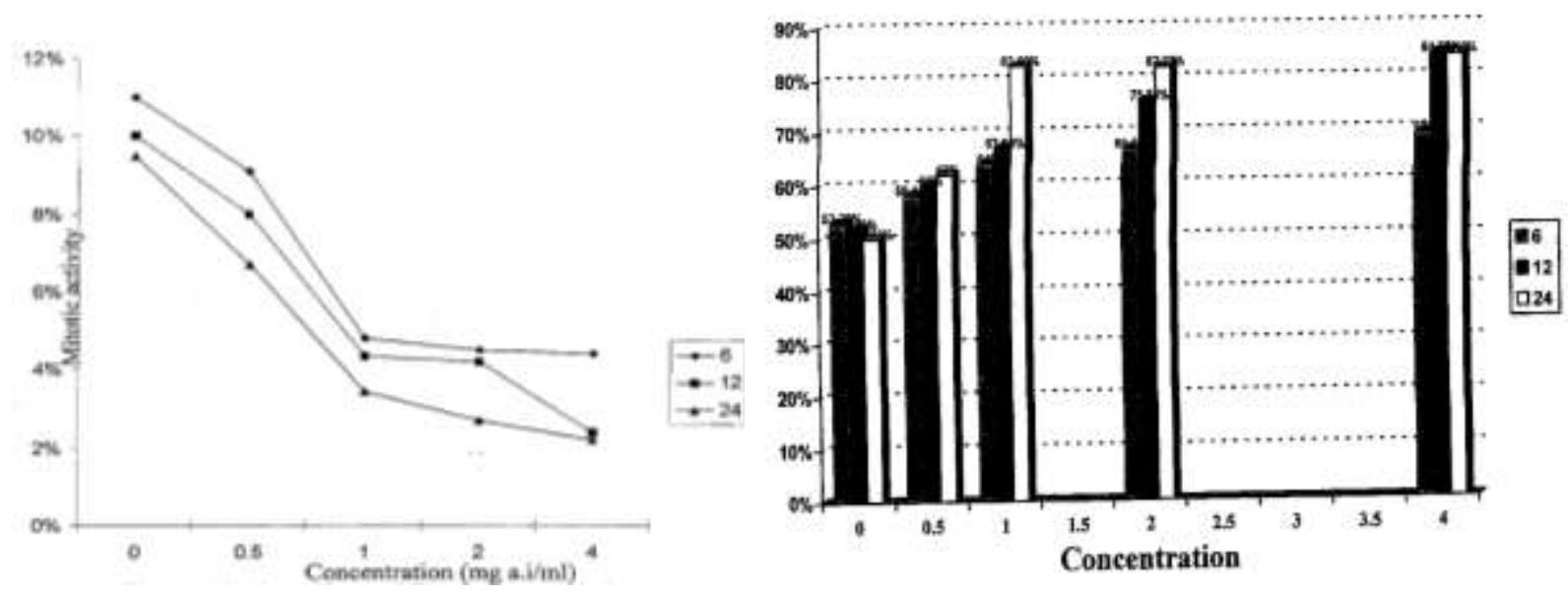

\section{Figure 1. The effect of Furadan( upon) the mitotic activity of Allium cepa root- tip cells after three treatment times $(6,12$, and 24 hrs.)}

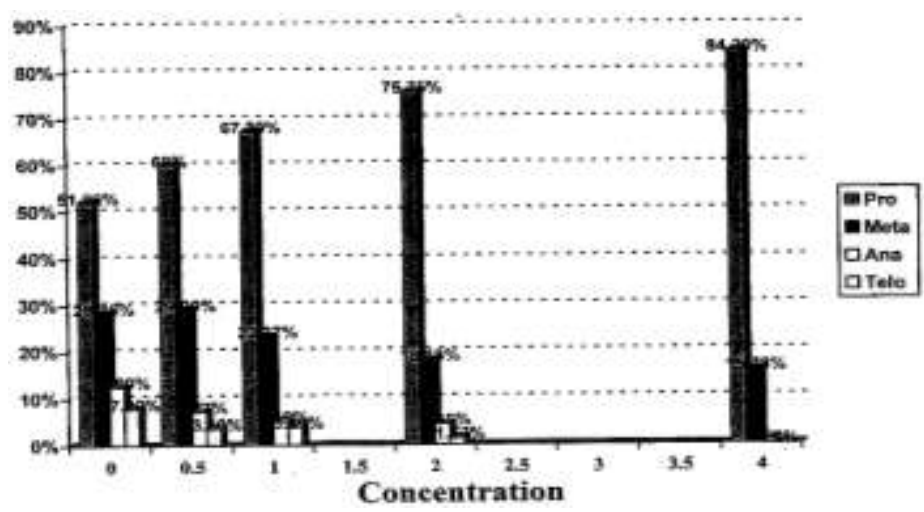

Figure 2.The effect of 4 times concentration of Furadan on prophase indices for 3. 
Figure3.Phase indices of onion (Allium cepa) root- tip cells for 4 concentration at 12 treatment with Furadan.

Figure 4.Photomicrograph showing Anaphase with Stickiness and chromatid deletion after treatment with Furadan

Figure5.Photomicrograph showing Anaphase with chromatid deletion after treatment with Jojoba leaf extract 


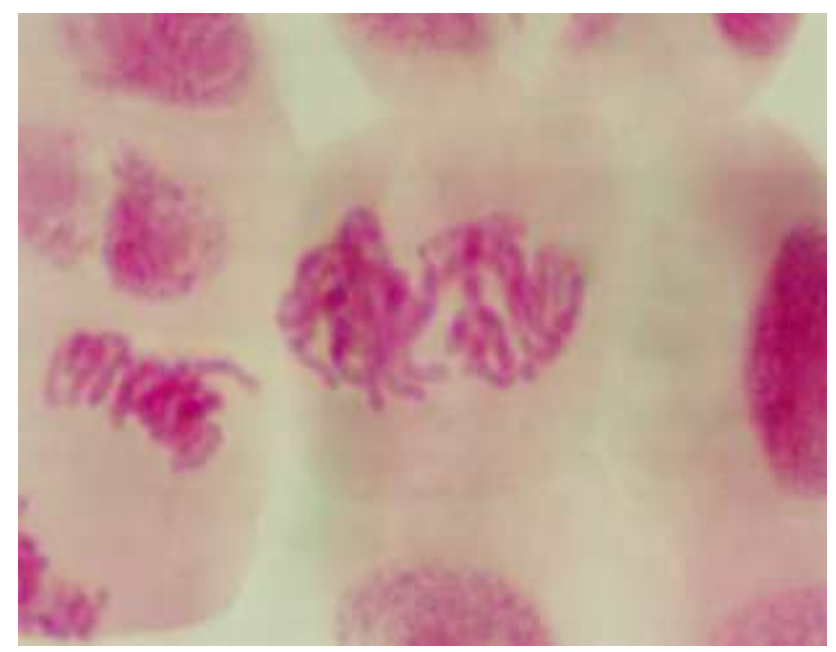

Figure 6. Photomicrograph showing Anaphase with Stickiness chromatid deletion after treatment with Furadan

Figure 7. Photomicrograph showing Tripolar Anaphase after treatment with Furadan

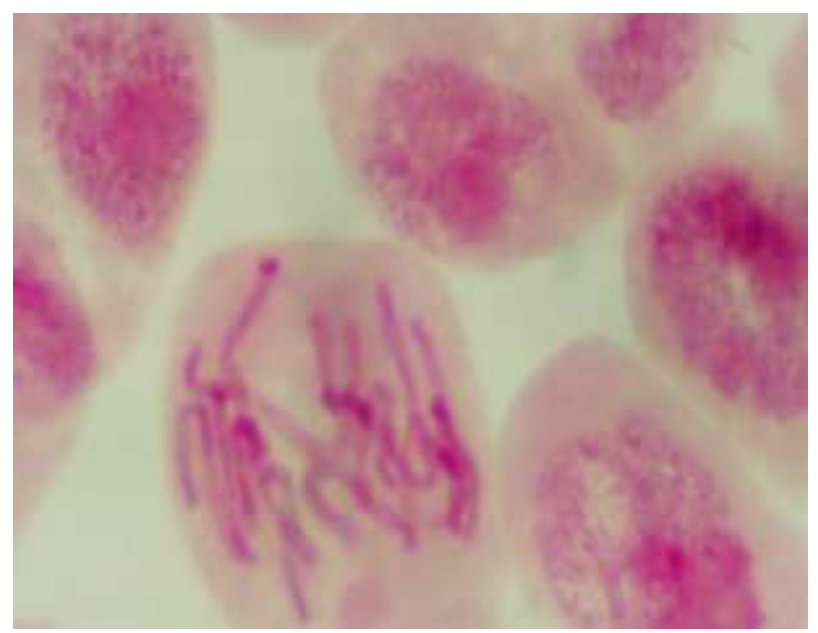

Figure 8. Photomicrograph showing metaphase and gap 


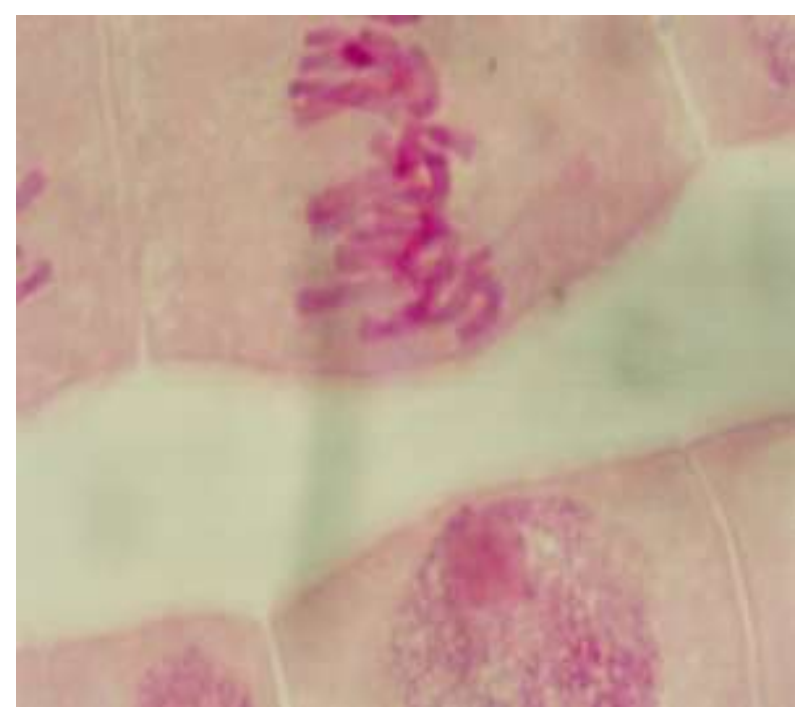

Figure 9. Photomicrograph showing metaphase with stickiness

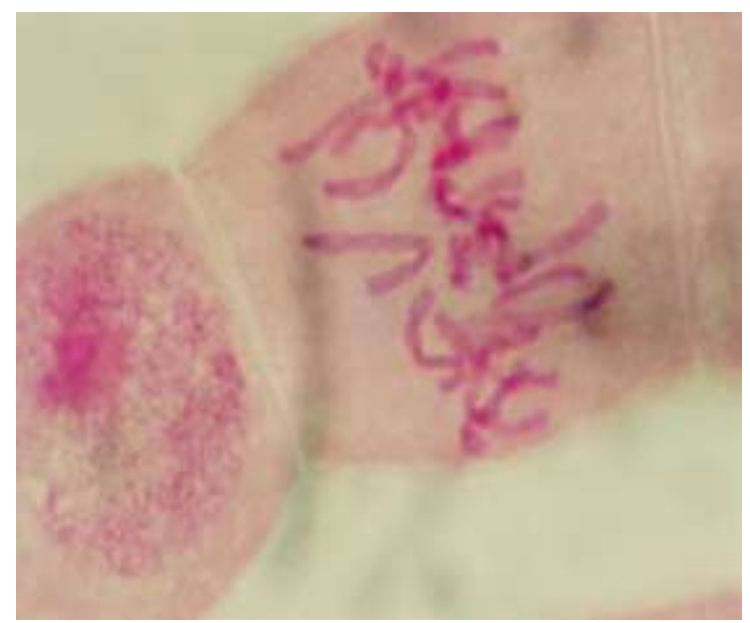

Figure 10. Photomicrograph showing chromosome gap and chromosome fragment

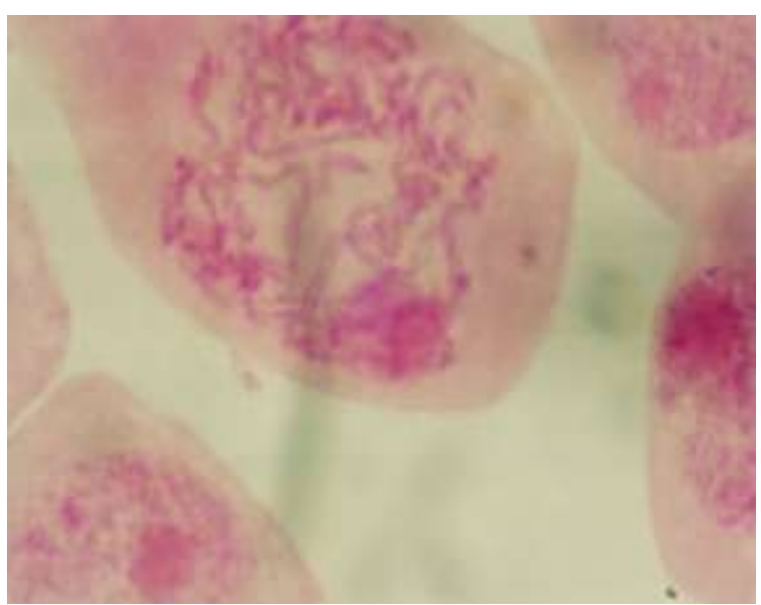

Figure11. Photomicrograph of Prophase showing uncoiling 


\section{REFERENCES}

Abdel Maksud, S, A, (2003). Differantial DNA Content and Development of Nematode. MS.c Thesis Fac. Of Agric. Alexandria University

Amarger, V. and Mercier (1995). Molecular analysis of RAPD DNA based markers: Their potential use for the detection of genetic variability in Jojoba (Simmondsia chinensis L Schneider). Biochimie 77(12): 931-936.

Amin, S. (2013). Genotoxicity of jojoba (Simmondsia chinensis) extracts employing a variety of short - term genotoxic bioassays. Ph.D. Thesis, Fac. Agric. Alexandria University.

Bashir, M., M. Anjum and H. Rashid (2008). In Vitro propagation of some promising genotypes of jojoba (Simmondsia chinensis). African Journal of Biotechnology 7 (21): 3878-3886.

Dolezel, J., Dolezelova, M., and Novak, F. J., (1994). Flow cytometric esyimation of nuclear DNA amount in diploid bananas (Musa acuminata and M. balbiana) Biologia Plant arum 36 (3): 351-357.

Inserra, R. N., Vovlas, N., O'Bannon., J. H., and Griffin, G. D. (1985). Development of meloidogyne chitwoodi on Wheat. Journal of Nematology 17 (3): 322 - 326.

Kevers, C., Greimers, R., Franck, T., Bisbis, B., Dommes, J., and Gasper, T., (1999). Flow Cytometry estimation of nuclear of sugar beet. Biological plant arum 42 (3): 321 332.

Khan, A., Shaukat, S. S. and Ahmed, I., (2001). Effect of organic Manures and Carbofuran on Nematodes Associated with Garlic ( allium Sativam L.) Pakistan of Biological Science. 4 (3): 319 - 320
Michaelson, M. J., Price, H. J., Ellison, J. R., Johanston, J. S. (1991). Comparison of plant DNA contents determined by feulgen microspectro photometry and laser flow cytometry. Amer J. Bot. 78: 183 - 188.

Mills, D., Z. Yanqin and A. Benzioni (2009). Effect of substrate, medium composition, irradiance and ventilation on jojoba plantiets at the rooting stage of micropropagation. Scientia Horticlturae 121 (1): 113-118.

Minton, N. A. and Admson, W. C., (1979). Control of meloidogyne Javanica and M. arenaria on Kenaf and roselle with genetic resistance and nematicides. Journal of nematology, 11 (1): $37-43$.

Mohasseb, A. Heba, M. El-Bahr, Zakia, Adam, H. Moursy, and M. Solliman (2009). In Vitro Clonal Propagation of Jojoba (Simmondsia chinensis (Link) Schn.) Australian Journal of Basic and Applied Sciences 3(4):3128-3136.

Sediqui, M.A., Azam, F. and Saxena, S.K. (1998). Evaluation of chemical Pesticides againest the root-knot Nematode on Aubergine. Ann. Appl. Biol. 132.

Seehy, A.M. and Hafez, M. A. (1994). Genotoxicity of contraceptive. 1st enternational conference on enveron mental mutagensis. On human population at risk Egypt, Cairo, Junuary, 1992, 19 - 24.

Seehy, M., Y. A. Mostafa and M. A. Osman (1989). Evaluation of nystatin genotoxicity- Mitotic nondisjunction in S. cerrsiae and Allium cepa chromosomes. Bull. Of Alex. Fax. Med. Vol. Xxr no. 6: 1625-1631.

Sharma, K., V. Agrawal, S. Gupta, R. Kumar and M. Prasad (2008). ISSR marker-assisted selection of male and female plants in a promising dioecious crop: jojoba (Simmondsia chinensis). Plant Biotechnol Rep. 2:239-243.

Taylor, A. L., and J. N. Sasser (ed) (1978). Biology identifecation and control of root-knot nematodes North Carolina State University Graphic, Releigh, NC, U.S.A $111 \mathrm{pp}$. 


\section{الملخص العربي}

\section{مستخلص أوراق الجوجوبا يحدث أثرا مضادا للنيماتودا}

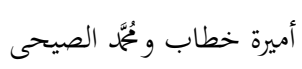

المادة الجافة/ أصيص يحتوى نباتين طماطم ثم عدوتما مسبقاً بـ 5000 بيضة من النيماتودا M. incognita وبعد مرور 30 يوم من المعاملة لمنافين

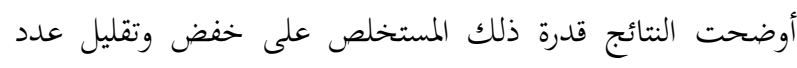
البيض وكذلك عدد كتل البيض وعدد اليرقات في كلا المعاملتين. ووجد أن الفيوردان كان أكثر قدرة على تقليل عدد البيض وعدد البيد يرقات الطور الثانى وأيضاً عدد كتل البيض المتكونة على الجذور وفئ تلفيل

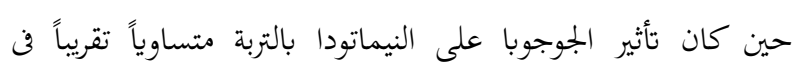
المعاملتين إلا أنه أقل فاعلية من المبيد المستخدم: لماتير. ومن هذا يتضح أن مستخلص أوراق نبات الجوجوبا له أثر مضاد

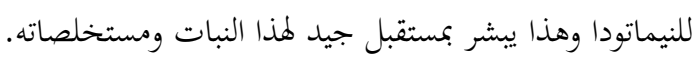

هدف هذا البحث لدراسة أثر مستخلص نبات الجوجوبا كمضاد

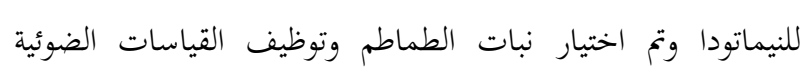

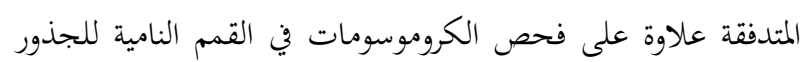

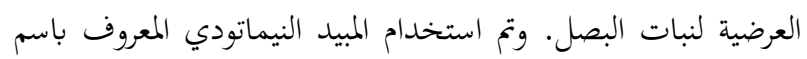

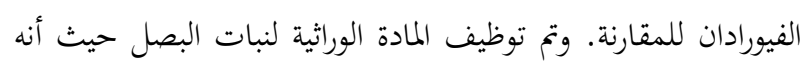
كشاف حساس لدراسة تاثير السمية الوراثية. وكذلك اهتم البحث بمقارنة تأثير مستخلص أوراق نبات الجوجوبا

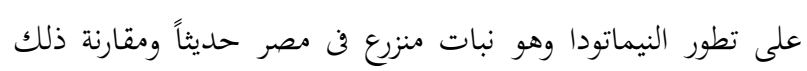
بتأثير الفيوردان على تطور النيماتودا أيضاً. وقد أوضحت النتائج أن أن أنسان

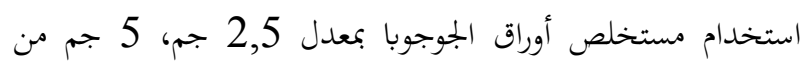

